\title{
Effect of the Grafting Method on the Recovery and Growth of Juvenile Shea (Vitellaria Paradoxa Gaertn C.F) Plants Grafted in Nursery
}

\author{
YAO Saraka Didier Martial ${ }^{1 *}$, Diarrassouba Nafan ${ }^{1}$, ALUI Konan Alphonse ${ }^{2}$, FOFANA Vamara Paterne ${ }^{1}$, BLE Pkagni Antoine ${ }^{1}$, \\ Diallo Rokia $^{1}$, KONE Brehiman ${ }^{3}$ \\ ${ }^{\mathrm{T}}$ Department of Biochemical and Genetics, Faculty of Biological Sciences, University of Peleforo Gon Coulibaly (UPGC), BP 1328 Korhogo, Côte \\ d'Ivoire \\ ${ }^{2}$ Department of Geosciences, Faculty of Biological Sciences, University of Peleforo Gon Coulibaly (UPGC), BP 1328 Korhogo, Côte d'Ivoire \\ ${ }^{3}$ Word Agroforestry Centre (ICRAF), Nœud Sahel BP E5118 Bamako, Mali
}

Article History

Received: 11.11 .2020

Accepted: 17.12 .2020

Published: 30.12 .2020

Journal homepage: http://www.easpublisher.com

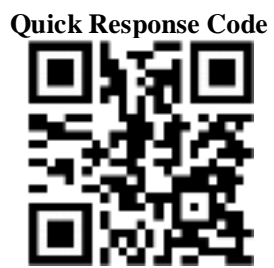

Abstract: The control of the factors that influence grafting would help significantly to improve the yield of grafted plants for the benefit of shea breeding program and farmers of Côte d'Ivoire. The study aims to assess the influence of the grafting method on the recovery and growth of grafted shea plants in nursery. The grafting was carried out in nursery onto 2-year-old rootstocks. Two grafting methods that are terminal slit grafting and side-grafting in sap-wood were tested in the nursery in randomized design. The results showed that the method of graft has a significant effect on the grafted plant recovery and agronomic trait growth. Terminal slit grafting recorded the highest recovery rate (90\%), rapid recovery time (21 days) and high mean values of agronomic growing traits (1.63 twigs per month, 5.59 leaves per month and $3.28 \mathrm{~cm}$ of height growing per month) in grafted plants. These results were permit to retain terminal slit grafting as the best grafting method to apply in shea in nursery in order to supply masse grafted plants to the farmers in Côte d'Ivoire.

Keywords: Shea tree, grafting method, recovery, vegetative growth, nursery.

Copyright (C) 2020 The Author(s): This is an open-access article distributed under the terms of the Creative Commons Attribution 4.0 International License (CC BY-NC 4.0) which permits unrestricted use, distribution, and reproduction in any medium for non-commercial use provided the original author and source are credited.

\section{INTRODUCTION}

Vitellaria paradoxa Gaertn F. commonly named shea tree from Sapotaceae family is endemic to Africa and grows in the Sudanese savannas of South Sahara [1]. There are two main subspecies in $V$. paradoxa. These are the paradoxa subspecies which grows in West Africa and the nilotica subspecies which mainly grows in Northern Uganda and Southern Sudan $[2,3]$. The shea tree produces fruits with edible pulp containing kernel rich in fat $[4,5]$. The uses of shea tree are numerous. The shea tree is used for nutrition, pharmacopoeia, energy, crafts, cosmetics, etc. [4]. In Côte d'Ivoire the exploitation of the shea tree presents as an alternative to reduce both the poverty of the populations in the North and the rural exodus by providing jobs to young people and women.

Until today, although the large results of studies on the shea tree botanical description [6-8] are recorded, the reasons for the loss of fruit production [9, 10], the species agromorphological diversity [1, 11-13], the seed multiplication [14] and vegetative propagation [15] have enriched species knowledge, the problem relating to shea domestication and improvement remains. Recently in Côte d'Ivoire, research activities carried out about vegetative multiplication allowed the shea breeding program to initiate by grafting the multiplication of elite genotypes identified in village lands $[13,15]$. While sexual reproduction by seed leads to heterogeneity in the produced plant material, vegetative propagation by grafting aims at identical reproduction of plants (elite shea tree supplier of the grafts) with desirable agronomic traits (high productivity, superior quality of fruit and seed, good tolerance to biotic or abiotic stress). Thus, it makes it possible to multiply by grafting an agronomic interest trait [16].

In the context of improving shea tree in Côte d'Ivoire, the use of grafting is justified for reproducing and disseminating to the elite shea trees identified in village lands $[13,15]$. Also, it is possible to reduce the adolescence period of the shea tree and to preserve interesting genotypes in the field collections for the needs of research and development [15]. However, the results relating to the success rates of the transplants performed in nursery are heterogeneous. This reveals the lack of control of the main factors involve the success of shea grafting in nursery. To understand the factors impact the success of grafting in plant, several 
hypotheses such as grafter technicality, plant material quality (rootstock and graft) and grafting method were previously reported [17]. Other exogenous factors affecting graft successes such as hygiene during grafting, ambient temperature and humidity have also been reported [16]. The general objective of this study is to know the effect of two grafting methods, terminal slit grafting and side-grafting in sap-wood, on the recovery and growth in juvenile shea plants grafted in nursery.

\section{Material ANd Methods Study site}

The study was carried out on the production platform of shea plants located in the vegetable patch of the botanical garden of the University Peleforo Gon Coulibaly (UPGC) in Korhogo. The locality of Korhogo is located between $8^{\circ} 32^{\prime}$ and $10^{\circ} 20^{\prime}$ North latitude and between $5^{\circ} 16^{\prime}$ and $6^{\circ} 16^{\prime}$ West longitude. The annual average temperature is $28.91{ }^{\circ} \mathrm{C}$ at Korhogo. The dry season runs from November to April and the rainy season covers the period from May to October. The rainy season has an annual rainfall of around 1, $200 \mathrm{~mm}$ per year. The months of January and February are the driest in Korhogo. The platform of the shea plant production has a shade house to ensure homogeneous shade for juvenile shea plants raised in order to avoid plant burns and rapid drying out of the nursery substrate due to high temperatures during the long dry season in the north of the Côte d'Ivoire.

\section{Plant material}

The plant material consisted of 30 shea juvenile rootstocks and 20 shea grafts (Figure 1). The rootstocks used consist of juvenile shea from seed germination in nursery for 2 years. The growing medium for the rootstocks consisted of equal quantities of sand, manure and muck. These three substrates were mixed homogeneously and supplemented with a fungicide sold at the market. The grafts were collected from an elite shea tree wildly grew in an agroforestry park. The grafts carefully collected in the field, labeled and stored in a cooler were transported to the plant production platform at the UPGC.

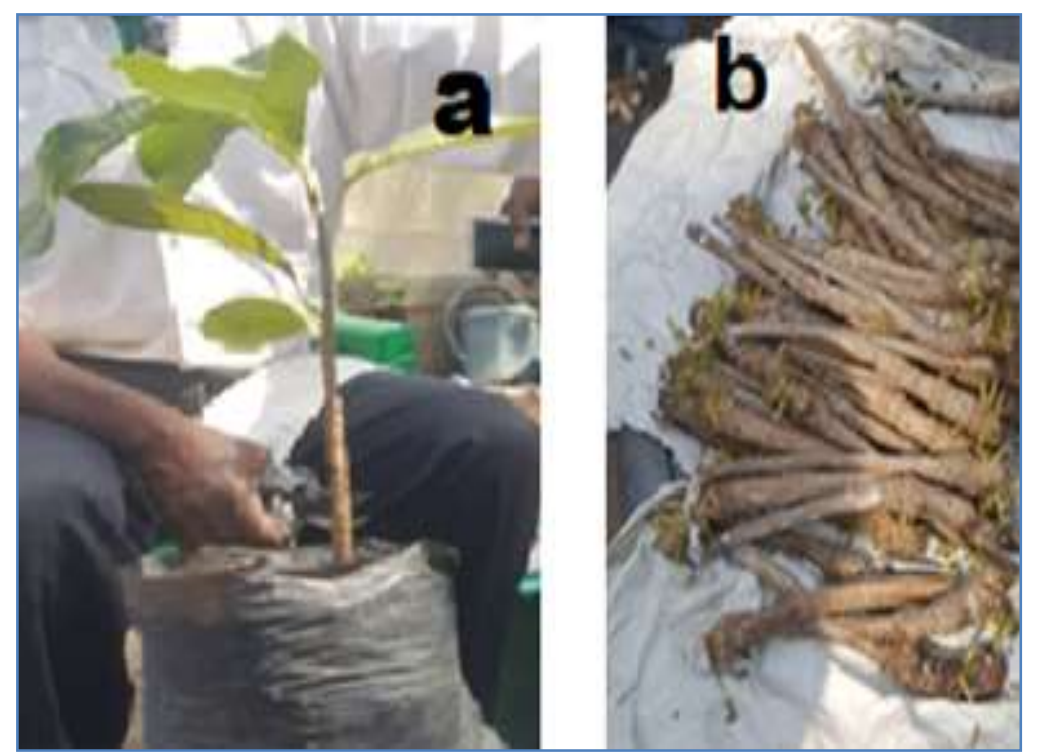

Fig-1: Plant material used in the study (a) Juvenile rootstocks of two years old in nursery; (b) grafts harvested from the field

\section{Experimental design}

The randomized design was used to test the effect of the factor grafting method with two levels, terminal slit grafting and side-grafting in sap-wood (Figure 2). In this experimental design, each of the levels of the factor studied had 10 repetitions. Therefore, 20 grafts were performed in February 2019. Along with the juvenile rootstocks treated by grafting, 10 ungrafted rootstocks were included in the experiment to serve as a control during growth dynamic assessment. Thus, the experimental design included 30 individuals (10 grafted plants treated with terminal slit grafting, 10 plants grafted with side-grafting in sapwood and 10 ungrafted plants). The factor studied (grafting method) varied while the genotype of the graft used remained fixed. The two grafting methods tested, the terminal slit grafting and side-grafting in sap-wood, have previously been described in detail by Yao et al. [15]. The juvenile plants grafted in the nursery pots were placed under a shade house where no gradient of heterogeneity is suspected. 


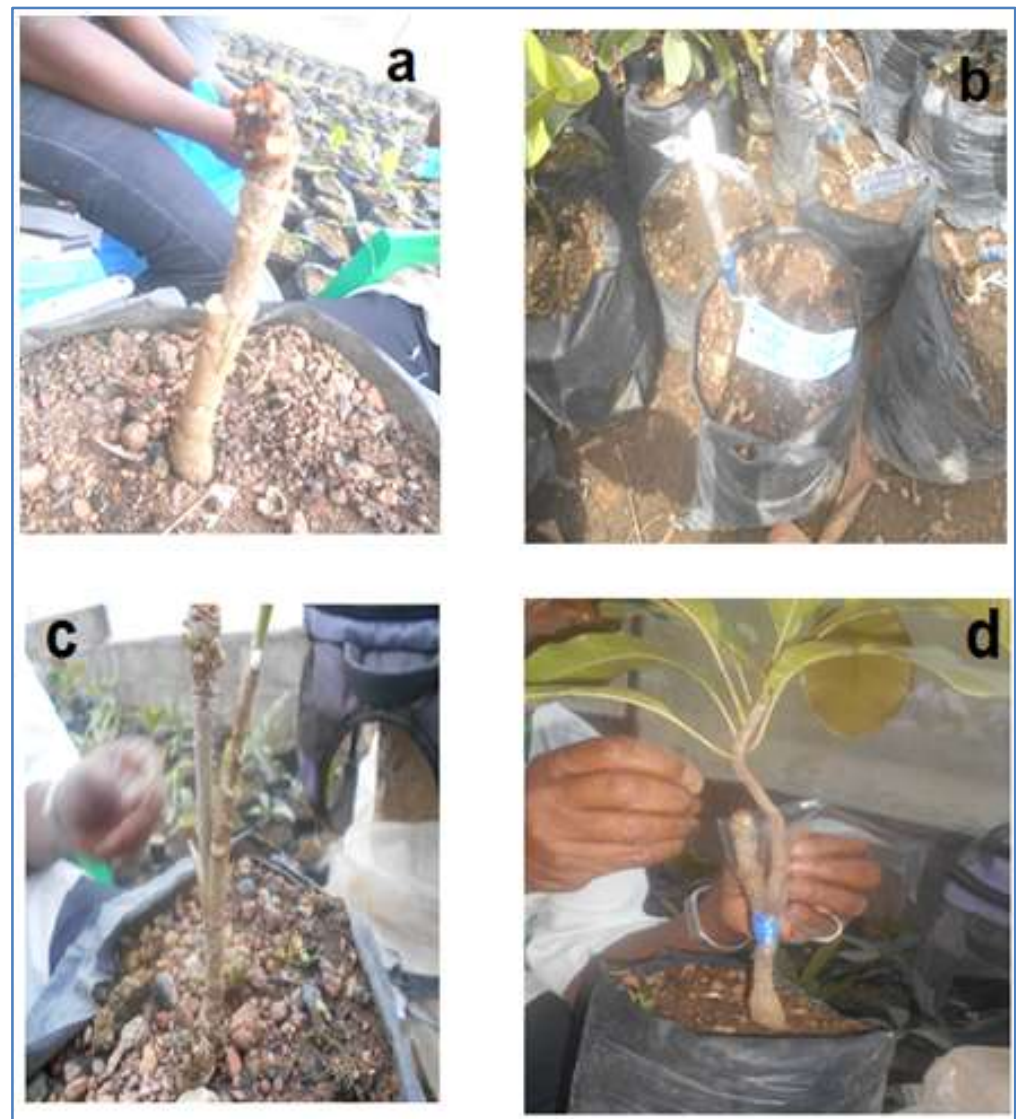

Fig-1: Grafting achievement at the nursery, a - b Terminal slit grafting, c - d : Side-grafting in sap-wood

\section{Agronomic data collection}

Agronomic data were collected on the grafted plants after grafting and ungrafted plants. Thus, the recovery time of the juvenile grafted plant was noted after observing the budding of the graft according to Yao et al. [15]. The number of survival grafted plants was counted and a recovery rate calculated for each grafting method according to the formula:

$$
\text { Recovery rate }(\%)=\frac{\text { Number of survival grafted plants }}{\text { Total number of grafted plants }}
$$

In addition, vegetative growth traits were evaluated 2 months, 3 months and 4 months after grafting both on the grafted plants (terminal slit grafting and side-grafting in the sap-wood) and the ungrafted plants. Traits assessed were number of leaves, number of twigs and total plant height. The averages of the velocity of twig emission (VTE) or leaf emission (VLE) or height growth (VHG) of the grafted or ungrafted shea plant were calculated following the formula propose by Lekadou et al. [18]:

VTE or VLE ou VHG $=\frac{x_{t n+1}-X_{t n}}{t_{n+1}-t_{n}}$

With:

VTE : average velocity of twig emission,

- VLE : average velocity of leaf emission,

- VHG : average velocity of height growth,
- $X_{t n+1}-X_{t n}$ : gap between values $(X)$ observed at the times $t_{n+1}$ et $t_{n}$ for a trait,

- $t_{n+1}-t_{n}$ : Time in months between two successive observations.

\section{DATA STATISTICAL ANALYSIS}

To test the effect of the grafting technical factor on the recovery time and rate of the grafted plant, a Student's test was carried out at a probability threshold of 5\%. To calculate the average recovery rate, the successful grafts were coded 0 and the unsuccessful grafts coded 100. Analysis of variance (ANOVA) was performed to test the significance of the grafted plant (terminal slit graft and side-grafting in the sap-wood) and ungrafted growth at a threshold of 5\%. When the ANOVA test was significant ( $\mathrm{p}<0.05$ ), a post-ANOVA test named Student Newman Keul (SNK) was performed to classify the statistical units studied. All these analyze were carried out by SPSS software version 20.0 (IBM Inc., USA).

\section{Results AND DiscuSSION \\ Effect of the grafting method on the recovery rate of the grafted plants in nursery}

The recovery rates were significantly different $(\mathrm{t}=2.276 ; \mathrm{p}=0.029)$ when terminal split grafting $(90 \%)$ and side-grafting in sap-wood $(60 \%)$ were applied to juvenile shea plants in the nursery ( Figure 3 ). The mean value of recovery time of the grafted plant 
significantly differentiated the two grafting method applied $(\mathrm{t}=-5.728 ; \mathrm{p}<0.001)$. The grafting method significantly influences the recovery rate of grafted plants in shea. Terminal slit grafting was more successful in the nursery than side-grafting in sapwood. Similar results were reported in african plum [19] and Ricinodendron heudelotii commonly known as "Apki" in Côte d'Ivoire [20]. However, higher recovery rates of side-grafting in sap-wood than the ones recorded from terminal slit grafting have been reported in juvenile cashew trees [21-23] and Apki [20] in the nursery. Batamoussi et al. [22] explain the high recovery rate recorded from side-grafting in sap-wood by the fact that this method provides higher humidity to the grafts with compared to terminal slit grafting. The present study highlights the importance of plastic film using for entire graft protection during terminal slit grafting in shea as described in detail by Yao et al. [19]. This helps prevent the graft from drying out and therefore gives better recovery.

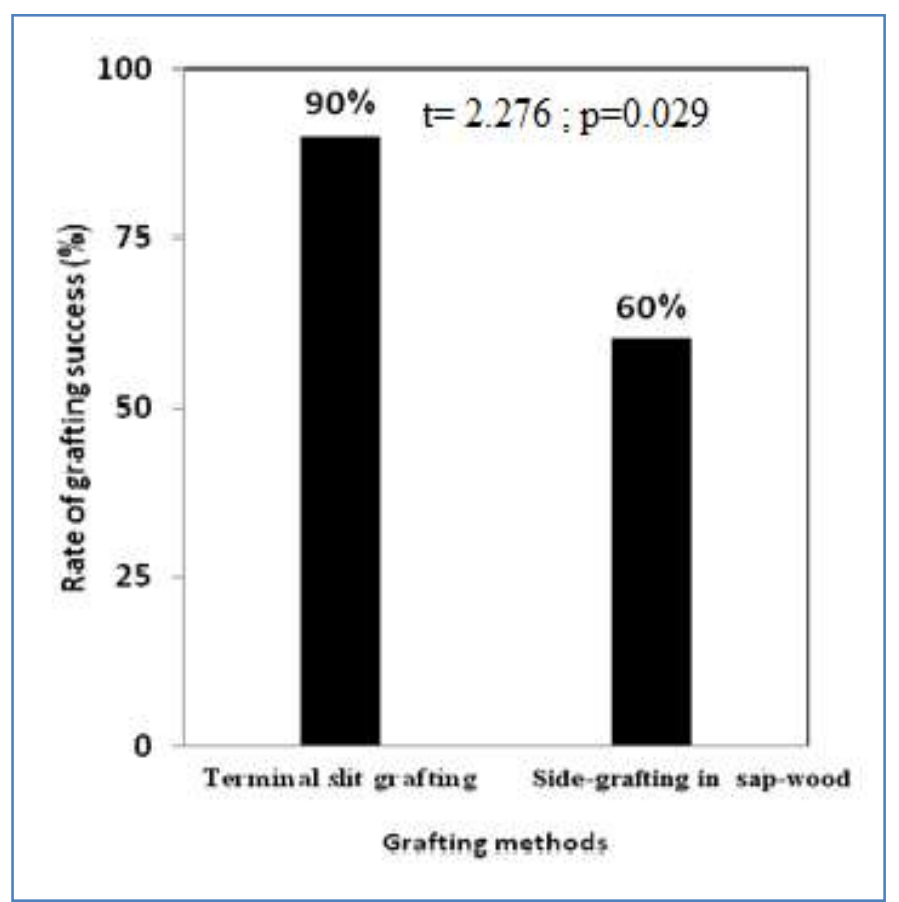

Fig-3: Rate of grafting success in relation to grafting methods in nursery and associated statistic values

\section{Effect of the grafting method on the recovery time of the grafted plants in nursery}

The weak values of recovery times (18 to 25 days) were recorded when the terminal slit graft was applied with an average of 21 days. For side-grafting in sap-wood, longer recovery times were recorded varying between 24 and 38 days with an average of 31 days (Figure 4). The terminal slit grafting of juvenile shea plants in nursery gives a significantly shorter recovery time than that of side-grafting in-sapwood. This result reveals that the adhesion between the rootstock and the graft is faster when the terminal slit grafting is performed. Indeed, it is reported that the fusion between scion and rootstock does not occur directly, but takes place between newly formed tissues. In the contact area, a callus or scar tissue is formed from the xylem and phloem of the two sections of the rootstock and the graft in contact [16]. It therefore appears that the process of callus proliferation (callogenesis) by mitosis for healing and the union between graft and rootstock is faster when a terminal slit grafting is realized in shea tree. In the terminal slit grafting, the graft seems to have benefited from good water and mineral nutrition. Regardless of the grafting method, the recovery times for juvenile shea plants in the nursery vary between 18 to 38 days. These nursery recovery times found include the average recovery time reported by Yao et al. [15] in shea in Côte d'Ivoire (21 days). Also, similar results have been reported on juvenile cashew trees grafted in nursery in Côte d'Ivoire where the recovery rates varied from 22 to 26 days [24]. However, the data reporting about the recovery rates of juvenile cashew trees grafted in nursery seems fluctuating because shorter recovery times (14 to 19 days) have been recorded in Benin [22]. 


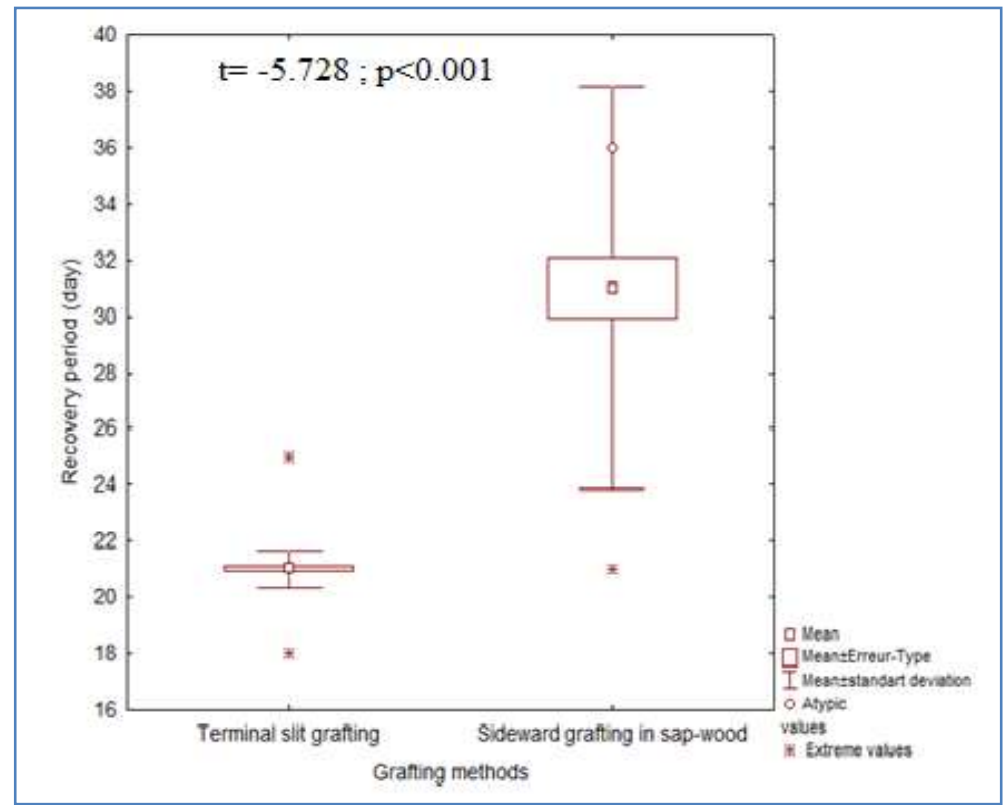

Fig-4: Mean of recovery period of the grafts in relation to grafting methods in nursery and associated statistic values

\section{Dynamics of the number of twig and leaf emission and height growth of the grafted shea plants in nursery}

Whatever the grafting method used, the growth of the grafted shea plants was significantly (ANOVA test; $\mathrm{p}<0.05$ ) faster than the ungrafted plants (Figure 5). The terminal slit grafting allowed significantly higher growth and vegetative development (ANOVA test; $p$ $<0.05)$ of the juvenile grafted shea tree than the ones grafted from side-grafting in sap-wood (Figure 6). The grafting method affects significantly the height growth, the emission of twigs and leaves in shea tree.

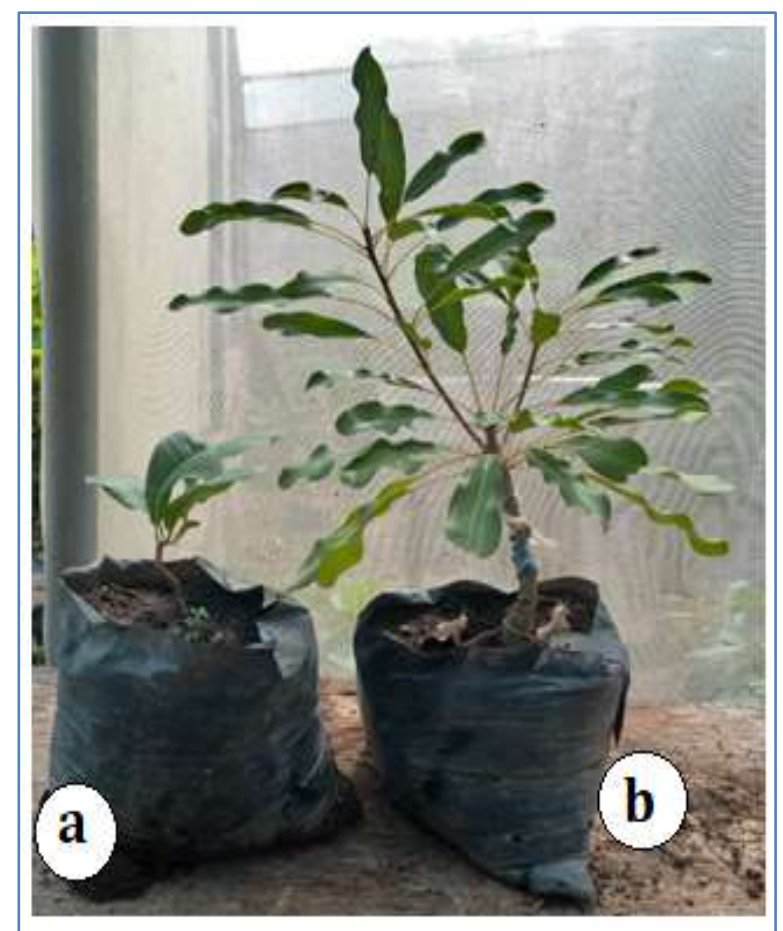

Fig-5: Grafted and ungrafted shea plants aged to 28 months in nursery (24-month-old before grafting and 4-month-old after grafting). A. Non grafted plant; b. grafted plant

From 2 to 4 months, the number of twigs on the grafted plants increased from 2 to 5 and from 0 to 2 when the terminal slit grafting and the side-grafting in sap-wood were applied in nursery. The number of twigs bear by the ungrafted plants from 3 to 4 months was lower compared to grafted plants in the nursery (Figure $6)$. Higher values of monthly twig number velocity were recorded in grafted plants and grafted plants where terminal slit grafting was applied (Table 1). 


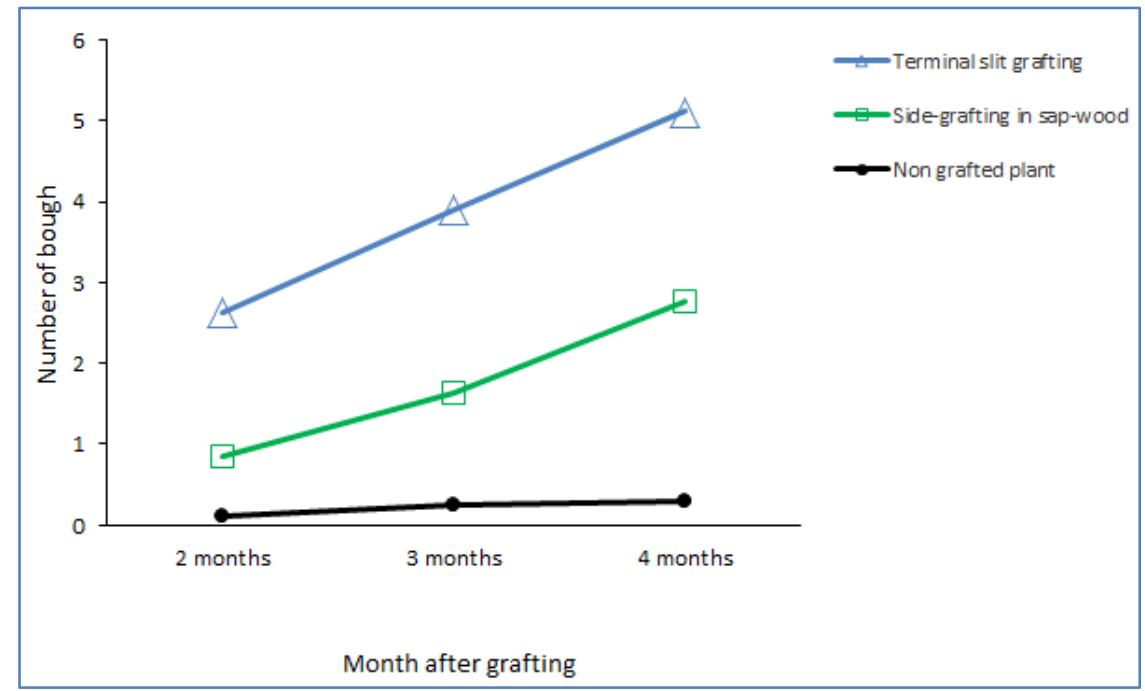

Fig-6: Dynamics of the number of twig emission monthly in grafted and ungrafted shea plants in nursery

Over the same period ( 2 to 4 months), the number of leaves on the grafted plant increased from 22 to 31 after the terminal slit grafting were applied and from 15 to 21 for the side-grafting in sap-wood. The number of leaves cast on the ungrafted plant varied from 5 to 7 (Figure 7). Monthly, the means of leaf emission rate in plants grafted from terminal slit grafting was 5.59 leaves, 4.61 leaves for plants grafted from side-grafting in sap-wood and 0.61 leaves for ungrafted plants. There is a significant difference, at the $5 \%$ threshold, between these velocities $(\mathrm{F}=19.356$ and $\mathrm{p}=0.019)$ (Table 1).

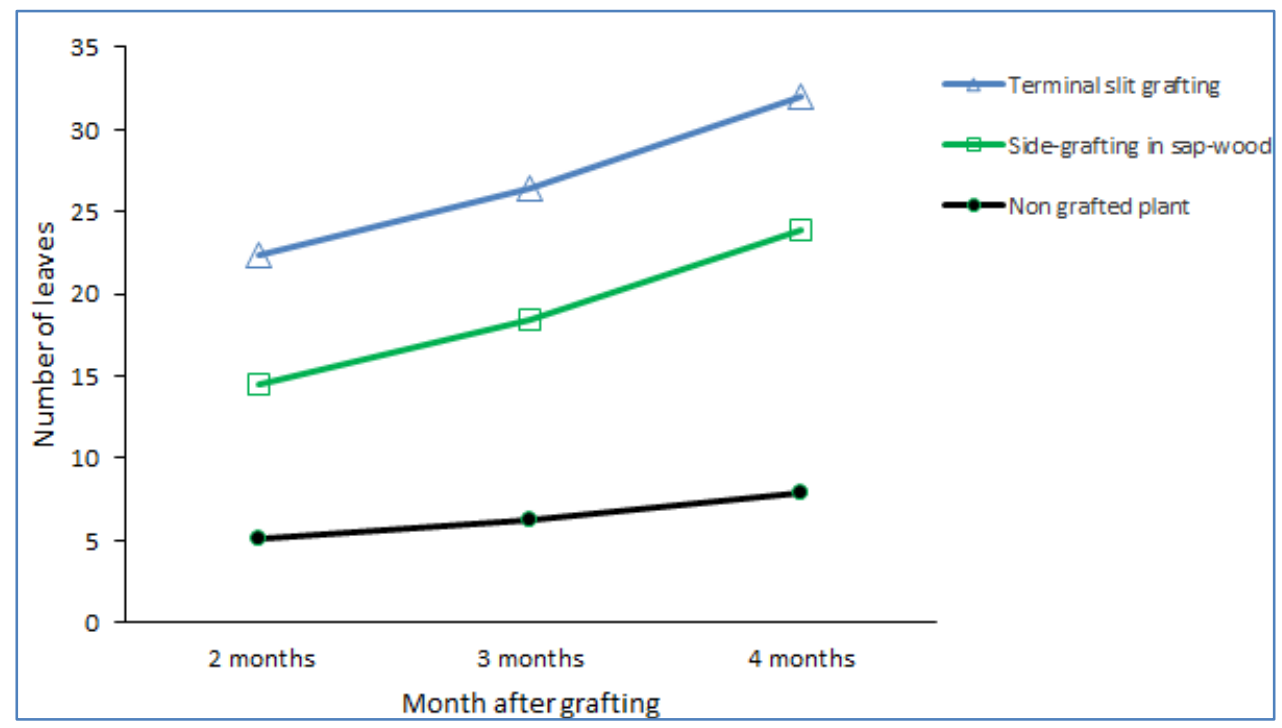

Fig-7: Dynamics of the number of leaf emission monthly in grafted and ungrafted shea plants in nursery

The height of the grafted plants increased from $24.94 \mathrm{~cm}$ ( 2 months) to $31.95 \mathrm{~cm}$ (4 months) when terminal slit grafting was applied and from $20.05 \mathrm{~cm}(2$ months) to 24.38 (4 months) when the side-grafting in sap-wood was applied. The height of the ungrafted plant varied from $10.25 \mathrm{~cm}$ to $11.10 \mathrm{~cm}$ over the same period (Figure 8). Higher values of monthly height grown velocity were recorded in grafted plants when terminal slit grafting was applied (Table 1).The grafted plant gives significantly higher average values of vegetative development than the ones recorded in ungrafted plants. However, the maximum value of monthly mean velocity of height increase found in juvenile shea plants $(3.28 \mathrm{~cm}$ per month) was lower than the one $(10 \mathrm{~cm}$ per month) reported by Gnanglé [25]. 


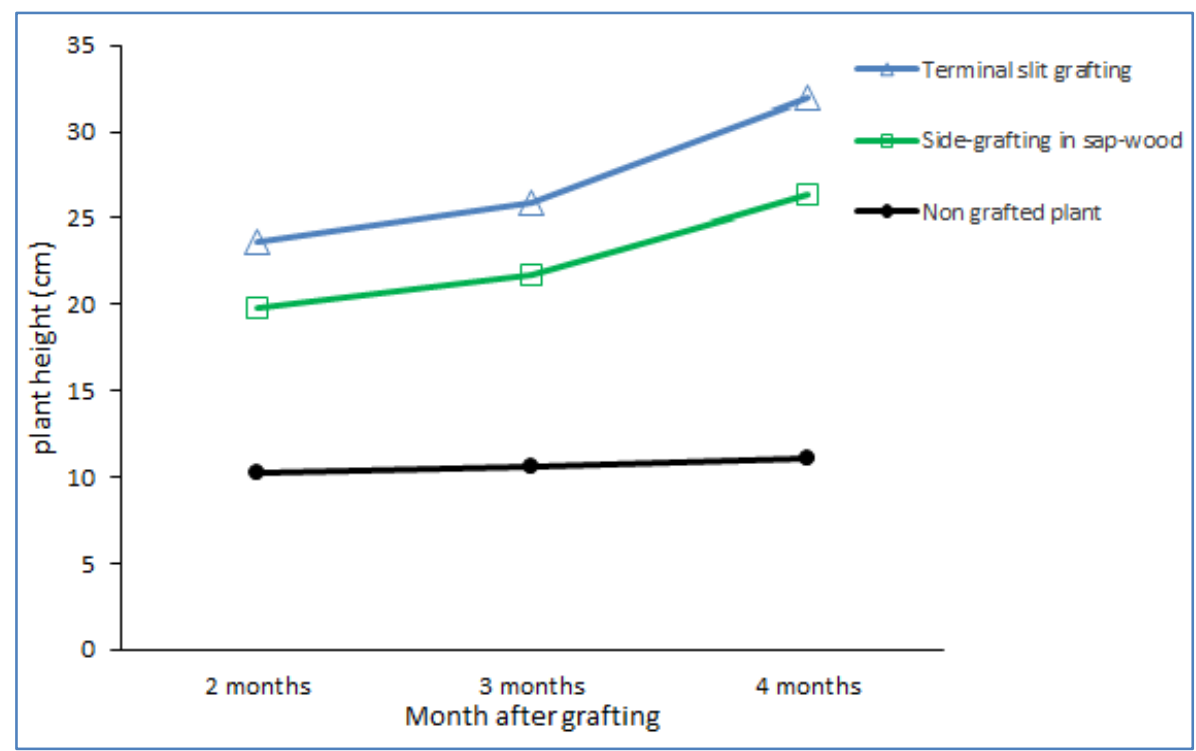

Fig-8: Dynamics of height growth monthly in grafted and ungrafted shea plants in nursery

The significant influence of the grafting method on vegetative growth has also been reported by Anyouzoa [20] about juvenile Apki plants grafted in nursery in Cameroon. The shorter recovery time recorded when shea plants treated with terminal slit grafting allows juvenile grafted shea plants to start their growth and vegetative development earlier. The strongest vegetative growth recorded in juvenile grafted shea plants, could be also explained by a more increased production of growth hormones that are auxins, cytokinins and gibberellic acid in the grafted plants. It would seem that the grafting operation would induce hormone production in transplanted individuals whose action is essential for callogenesis induction [26] to promote the fusion between the graft and the rootstock, the multiplication, the elongation and the differentiation of plant cells [27]. This hypothesis seems true because the factors which induce vegetative growth in plants reported are external factors (temperature, light, water nutrition, mineral nutrition, etc.), internal factors such as plant hormone [28] and the rootstock [24] in the case of grafted plants. The grafted shea plants having been subjected to the same external factors in the nursery and the rootstocks used having the same age and similar vegetative characteristics, only the internal factors, i.e. a higher hormonal production in the juvenile plants would be at the origin of the strongest vegetative growth recorded in the grafted plants. The grafting carried would cause stress in the grafted plant and stimulate the accumulation of carbohydrates and hormones promoting vegetative growth. Indeed, it has been reported that stress caused by annular incision of the trunk promotes better production by inducing an accumulation of carbohydrates and hormones in the twigs and leaves located above the trunk incision point in shea tree [11].

Table-1: Comparative analysis of the average growth rate of seedlings grafted in terminal slot, rib in sapwood and ungrafted plants of juvenile shea plants in the nursery

\begin{tabular}{|l|c|c|c|c|c|}
\hline \multirow{2}{*}{ Velocity increasing } & \multicolumn{2}{|c|}{ Mean of velocity \pm standard deviation } & \multirow{2}{*}{ F } & \multirow{2}{*}{ p- value } \\
\cline { 2 - 5 } & $\begin{array}{c}\text { Grafted plant from } \\
\text { terminal slit grafting }\end{array}$ & $\begin{array}{c}\text { Grafted plant from side- } \\
\text { grafting in sap-wood }\end{array}$ & $\begin{array}{l}\text { Ungrafted } \\
\text { plant }\end{array}$ & & \\
\hline Twig nomber (unity.month- $^{1}$ ) & $1.63 \pm 0.66^{\mathrm{a}}$ & $1.17 \pm 0.58^{\mathrm{b}}$ & $0.17 \pm 0.23^{\mathrm{c}}$ & 6.639 & 0.041 \\
\hline Leaf number (unity.month- $^{-}$) & $5.59 \pm 1.79^{\mathrm{a}}$ & $4.61 \pm 0.80^{\mathrm{b}}$ & $0.61 \pm 0.45^{\mathrm{c}}$ & 19.356 & 0.019 \\
\hline Plant height (cm.month- $^{1}$ ) & $3.28 \pm 1.88^{\mathrm{a}}$ & $2.24 \pm 1.36^{\mathrm{b}}$ & $0.34 \pm 0.39^{\mathrm{c}}$ & 6.756 & 0.032 \\
\hline
\end{tabular}

\section{CONCLUSION}

The aim of the study was to improve knowledges about shea grafting in nursery. At length these results could improve the success rate of shea grafting. It emerges that the young grafted shea plants present a recovery and a vegetative growth influenced by the type of graft. With a higher success rate, a shorter recovery time and better vegetative development, terminal slit grafting appears to be the best grafting method for juvenile shea plants grafting in nursery.

\section{ACKNOWLEDGMENTS}

The authors thanks to the Fond Compétitif pour l'Innovation Agricole (FCIAD) of Côte d'Ivoire and the Fond Interprofessionnel pour la Recherche et le Conseil Agricole (FIRCA), which fully funded this work through the fellowship agreement 1674/FIRCA/UPGC/FADCIFCIAD/2017 and plant nursery workers (Tra Bi Marc Hervé, Ouattara Souleymane, Kouame Jarod and Soro Nanougou) of shea breeding program of Côte d'Ivoire for help then data collection in nursery. 


\section{REFERENCES}

1. Diarrassouba, N., N'Guessan, A., Koffi, E., \& Sangare, A. (2007). Evaluation des performances de quelques descripteurs quantitatifs et leur utilisation dans la structuration de la population d'un parc naturel de karité en Côte d'Ivoire. Plant Genetics Resource Newsletter, 152, 65-72.

2. Bonkoungou, E., Zerbo, J., \& Billan, A. (1988). Multiplication végétative du karité (Butyrospermum paradoxum) au Burkina Faso. In IRBRT \& ISNIIDR (Eds.), Séminaire national sur la valorisation du karité pour le développement national. Bilan et perspectives (pp. 45-54).

3. Hall, J.B., Aebischer, D.P., Tomlinson, D.F., OseiAmaning, E., \& Dindle, J.R. (1996). Vitellaria paradoxa. A Monograph. School of Agricultural and Forest Sciences. University of Wale's Bangor.

4. Diarrassouba, N., Koffi, E.K., N'Guessan, K.A., Van Damme, P., \& Sangaré, A. (2008). Connaissances locales et utilisation dans la gestion des parcs à karité en Côte d'Ivoire. Afrika Focus, 21,77-96.

5. Kougblénou, N., Ahouansou, R. H., Aïssi, M. V., Houssou, P., Padonou, W., Fandohan, P., Mensah, G. A., \& Soumanou, M. M. (2012). Caractérisation physique du fruit et valeur nutritionnelle de la pulpe de karité (Vitellaria paradoxa) collecté dans différents parcs au Bénin. Bulletin de la Recherche Agronomique du Bénin, 1840-7099.

6. Chevalier, A. (1907). L'Afrique centrale française. Récit du voyage de la mission.

7. Delolme, A. (1947). Etude du karité à la station agricole de Ferkéssédougou. Oléagineux, 4,186200.

8. Aubreville, A. (1950). Flore Forestière SoudanoGuinéenne, A.O.F.- Cameroun- A.E.F.

9. Lamien, N. (2006). Fructification du karité (Vitellaria paradoxa Gaertn. F., Sapotacea ): Facteur de déperdition, Amlioration et Prévision des rendements à bondoukuy; Ouest du Burkina. Doctoral dissertation, University of Ouagadougou, Burkina Faso.

10. Lamien, N., Tigabu, M., Odén, P. C., \& Guinko, S. (2011). Effets de l'incision annulaire sur la reproduction du karité (Vitellaria paradoxa C.F. Gaertn.) à Bondoukuy, Burkina Faso. Fruits, 61, 259-266.

11. Diarrassouba, N., Fofana, I., Issali, A., Bup, N., \& Sangare, A. (2009). Typoloy of shea trees (Vitellaria paradoxa) using qualitative morphological trait in Côte d'Ivoire. Plant Genetic Resources Newsletter, 205, 10 -15.

12. Soro, D., Traore, K., \& Kassi, N.J. (2011). Variabilité des caractères morphologiques chez le karité (Vitellaria paradoxa) dans le Nord de la Côte d'Ivoire. International Journal of Biological and Chemical Sciences, 5(3), 1201-1214.

13. Yao, S. D. M., Diarrassouba, N., Attikora, A.J.F., Fofana, I.J., Dago, D.N., \& Silue, S. (2020).
Morphological diversity patterns among selected elite Shea trees (Vitellaria paradoxa C.F. Gaertn.) from Tchologo and Bagoué districts in Northern Côte d'Ivoire. International Journal of Genetics and Molecular Biology, 12(1), 1-10.

14. Alui, K.A., Diarrassouba, N., \& Yao, S.D.M. (2020). Germination Test of Shea Seeds (Vitellaria paradoxa C.F. Gaertn) in Nursery on Substrates of Northern Côte d'Ivoire. Asian Plant Research Journal, 3(2), 1-13.

15. Yao, S.D.M, Alui, K.A, Kouame, N. M., Ble, P. A., Kone, B., \& Diarrassouba, N. (2019). Réussir le « greffage en fente simple » et le « greffage de côté dans l'aubier » du karité. Journal of Applied Biosciences, 137, 13961-13972.

16. ICRAF. (2003). La multiplication végétative des ligneux en agroforesterie. Manuel de formation et bibliographie. World Agroforestry Centre (ICRAF), Nairobi (Kenya).

17. Ondo, O.P., Kebangoye, H., Medza, M., Nguema, N., Kevers, C., Dommes, J. (2018). Facteurs permettant d'améliorer la réussite au greffage des clones GT1 et PB217 d'Hevea brasiliensis (H.B.K.) (Muell. Arg) dans les conditions climatiques du nord Gabon. Journal of Animal \&Plant Sciences, 35, (3), 5749-5762.

18. Lekadou, T.T., Coffi, P.M.J., Yao, S.D.M., Ama, T.J. (2019). Vegetative Growth Response of Eggplant (Solanum aethiopicum L.) to Combined Effects of Fertilizer Types and Irrigation Regimes Applied on Littoral Tertiary Soil in Côte d'Ivoire. International Journal of Plant \& Soil Science, 30(5), 1-11.

19. Soloviev, P., Niang , T.D., Gaye, A. (2004). Propagation par greffage du prunier d'Afrique (Sclerocarya Birrea (A. Rich.) Hochst.) au Sénégal. Fruit, 59(4), 275-280.

20. Anyouzoa, A. (2003). Essai de greffage de Ricinodendron heudelotii en vue de sa domestication. XIIe congrès forestier mondial, Quebec, Canada.

21. Aliyu, O.M. (2001). Development of rapid method of propagating improved cultivars of cashew through budding, grafting and marcotting. Annual Research Report of the Cocoa Research Institute of Nigeria, Ibadan, Nigeria.

22. Batamoussi M.H, Mere T.O.B., Moussa I., Karami O.M., Amanoudo M.J., \& Lawson R.G.

(2017). Contribution à l'amélioration du taux de réussite du greffage de l'anacardier (Anacardium occidentale) en pépinière dans la commune de Parakou au Nord-Bénin. International Journal of Biological and Chemical Sciences, 11(5), 2270-2276.

23. Bognina, A., Guira, M., Yameogo, J.T., Tarpaga, V., \& Rouamba, A. (2019). Essai de multiplication par greffage d'une accession d'anacardier à grosses pommes à la Station de recherche de Banfora au Burkina Faso. Afrique science, 15(4), 156 - 168. 
24. Djaha, J.B.A, Adopo, A.A.N, Koffi, E.K., Ballo, C. K., \& Coulibaly, M. (2012). Croissance et aptitude au greffage de deux génotypes d'anacardier (Anacardium occidentale L.) élites utilisés comme porte-greffe en Côte d'Ivoire. International Journal of Biological and Chemical Sciences, 5(6), 1453-1466.

25. Gnanglé, P.C. (2016). Procédé pour booster la croissance de plants de karité et la production des fruits. Organisation Africaine de la Propriété Intellectuelle (OAPI).

26. Kawtar, L., Najat, H., Najiba, B., Najat, A., Najib, G., Elmustapha, E., Tarik, A., \& Hamid, B. (2015). Optimisation de l'induction de callogenèse à partir des embryons excisés de mandariniers (Citrus spp.). Journal of Applied Biosciences, 89, 8300- 8310.

27. Leclerc, M.E., Lapointe, L., Olivier, A. (2007). L'effet de phytohormones sur la multiplication végétative de la matteuccie fougère-à-l'autruche. Le naturaliste canadien, 131(1), 15-23.

28. Chahredine, S., \& Ykhlef, N. (2017). Etude Des Effets Des Régulateurs De Croissance Sur Les Stades De Prolifération Et De Développement De La Pomme De Terre (Solanum Tuberosum. L) In Vitro. European Scientific Journal, 13(24),145155. 